\title{
Transatlantic Connections in Colonial and Post-colonial Haiti: Archaeometric Evidence for Taches Noires Glazed Tableware Imported from Albissola, Italy to Fort Liberté, Haiti
}

\author{
Simone Casale ${ }^{1,2}$ (D) Joseph S. Jean ${ }^{1,2} \cdot$ Claudio Capelli $^{3}$. \\ Dennis Braekmans ${ }^{1,4,5,6}$. Patrick Degryse ${ }^{1,6}$. Corinne Hofman ${ }^{1,2}$
}

Accepted: 27 August 2020 / Published online: 1 October 2020

(C) The Author(s) 2020

\begin{abstract}
This paper presents the first archaeometrical data on colonial glazed wares (taches noires) imported in Haiti (Fort Liberté). The analysis evidenced the exclusive presence of Italian taches noires products, dated before 1820 and related to the colonial era. The presence of English wares next to colonial materials demonstrated continuity in the use of landscape after the Independence and the establishment of international trade relationships between the state of Haiti and the British Empire. Results are an important step forward in the understanding of production and movement of the Taches noires ware, which were exported globally between the eighteenth and nineteenth centuries.
\end{abstract}

Keywords Colonial ceramics · Haiti · Archaeometry $\cdot$ Ceramic technology $\cdot$ Glaze analysis

\section{Introduction}

The year 1804 marked a fundamental change in the history of the Americas. The colony of Saint-Domingue, after several years of war, declared its independence from the French Empire. Although much has been recently written on the Haitian revolution and on the political transformation of the French colony (e.g., Dillon and Drexler 2016; Dubois 2005; Dupuy 2019; Garraway 2008; Geggus 2014; Geggus and Fiering 2009; Ghachem 2012; Gómez 2017; Grüner 2019; Heath 2006; Horne 2015; Munro and Walcott-Hackshaw 2006; Nesbitt 2008), little is known on the practical changes that

Electronic supplementary material The online version of this article (https://doi.org/10.1007/s10761-02000559-3) contains supplementary material, which is available to authorized users.

Simone Casale

casale@kitlv.nl

Extended author information available on the last page of the article 
occurred in the daily lives of the emancipated enslaved population during the first years after the independence.

Colonial and post-colonial written sources usually comprise documents written by elites (Kelly 2013:2-3), excluding the rest of the population from key narratives. These sources usually leave out the life and experience of slaves and marginalized people, representing a restricted image of the society at that time. Practical changes in the daily life of marginalized peoples are often actively obscured and hidden in the background of major historical events.

Caribbean historical archaeology offers the opportunity to directly observe the cultural materials of the "invisible" people (Kelly 2013:2-3) and emancipated African diasporic communities, shedding light on their daily lives and of social changes during the colonial and post-colonial period. Several decades of research in the Caribbean on plantation socio-organization, and slave and maroon communities in the Anglophone colonies (e.g., Delle et al. 2011; Hauser 2008), Spanish territories (e.g., Arum and Garcia-Arevalo 1986; Deagan and Cruxent 2002; Deagan 1995; Domínguez 1989, 1991; Ewen 1991; Fairbanks and Marrinan 1983; Reitz 1986; Williams 1986; Woodward 2011), the French West Indies (e.g., Kelly 2002, 2004, 2013; Jean 2019; Monroe 2017) and the Dutch Caribbean (e.g., Barka 1996; Fricke et al. 2020; Gilmore 2006, 2011; Haviser 2001; Heath 1988, 1999) have begun to produce a solid base for understanding colonial life.

Studies on colonial archaeology in the French West Indies have mostly focused on Martinique and Guadeloupe (for synthesis see Kelly 2004, 2009, 2013; Kelly and Bérard 2014). Saint-Domingue, nowadays Haiti, in spite of being the richest French colony holding a prominent position during the colonial period within the West Indies, lacks considerable research from an historical archaeological perspective. Furthermore, knowledge regarding the first years of the Haitian independence is limited, particularly an understanding of the economic and cultural changes that took place during this time of political transition (Lacerte 1978:449).

To date, with the exception of some studies focused on the Spanish period (e.g., Deagan 1995; Ewen 1991; Fairbanks and Marrinan 1983; Reitz 1986; Williams 1986) and the recent works of Joseph S. Jean (2019) on the region of Fort-Liberté and Cameron Monroe (2017) in the area of Milot, little research has been done on Haiti. Historical documents are mainly used to explain the political, social, and economic configurations of Saint-Domingue's colonial landscapes. Although these studies are an essential introduction to archaeological research, more research must be conducted on the Haitian colonial and post-colonial past.

The present research is intentionally designed to challenge the present Haitian state of historical archaeological research and to draw attention to the importance of including more detailed area investigations, as was done by Monroe and Jean and to support studies with a detailed analysis on material culture remains. Micro-changes on the community-based level, such as the introduction of new types of goods, and changes in, or maintenance of domestic tools and traditions, can glean information to build a viable model of cultural and social change to explain the large-scale patterns of socio economic transformation that occurred in Haiti at the eve of the nineteenth century.

This study focuses on a minor aspect of trading activities embodied by a type of European glazed tableware, called taches noires ware (Cameirana 1980:277-293), in 
the area of Fort Liberté in the Département du Nord (Fig. 1). Taches noires production offers a clear chronology of manufacture, spanning from the end of the eighteenth to the first part of the nineteenth century. The original and most widespread production took place in Albisola, a town located on the north-west Italian coast, but minor imitation productions also existed in Spain and France (Capelli et al. 2017; Di Febo et al. 2018). The Italian ceramics were traded overseas by both French and Spanish merchants.

The aim of this research is to provide new insights into the economic and social contexts in which taches noires wares were transported and used primarily in the colony of Saint-Domingue, and possibly during the first years after independence in the Republic of Haiti. Saint-Domingue was culturally and economically entwined with the French metropolis until the end of the colonial period. However, during the postindependence period, the Republic of Haiti was mostly inhabited by formerly enslaved people who took possession of the areas previously owned by French landlords.

To understand the socioeconomic reorganization of Haiti, it is vital to assess if Haitians continued trading with France after 1804, or if economic and cultural connections ended after the War of Independence. Questions are raised regarding how Haitians reorganized the landscape and how they reused or abandoned plantations, military complexes, and urban areas that were previously owned by the French. Did they keep an economic connection with the French Empire, or did they start new trading relationships with other countries such as England, Spain, or the United States of America? This study focuses on analyzing the material evidence, in particular regarding relatively common products such as ceramics. Especially the provenance of one class of ceramics (taches noires) and the continuity in trade with Europe will be addressed. In this paper, we present petrographic observations and geochemical results (SEM-EDS and ICP-OES analyses) of taches noires wares from the areas of northeastern Haiti near Fort Liberté (see Fig. 1), compared with the data from newly analyzed kiln wasters from Albisola, Italy, as well as from previous reference studies on imitation taches noires wares from Barcelona (Di Febo et al. 2018) and three production centers in southern France (Roquefeuille, Cucuron, and Jouques) (Capelli et al. 2017). These new multidisciplinary data will allow us to establish a framework for our understanding of exchange, trade, and use of European goods (especially ceramics) in the northern part of the country before and after independence.
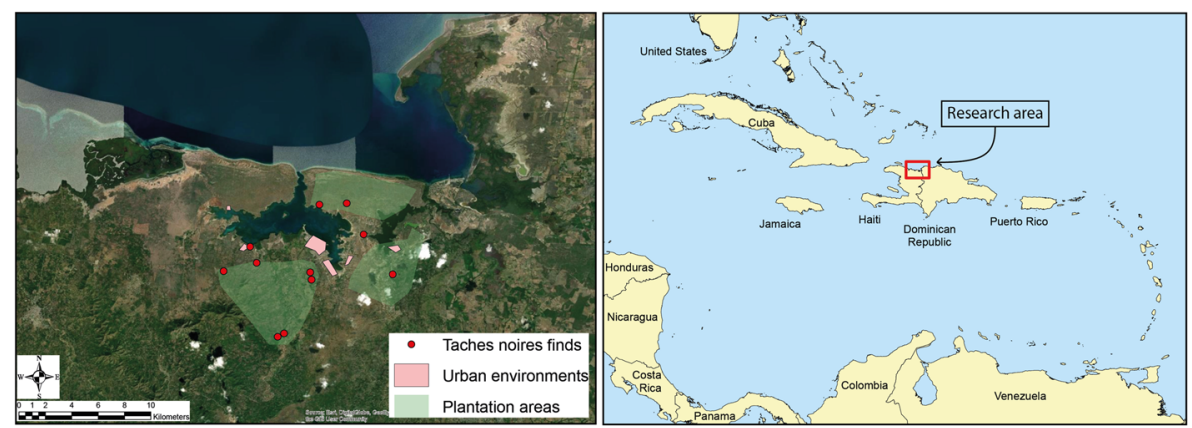

Fig. 1 The research area of Fort Liberté in north east Haiti 


\section{Historical background: Haiti}

After Haitian independence, new social, economic, and political organizations were established in the newborn nation. Jean-Jacques Dessalines was a leader of the Haitian revolution and became the first Haitian Emperor. In 1806, Dessalines was assassinated by conspirators who were against his social and economic policies (Hector 2009:243; Moïse 1988:36). Haiti was subsequently divided into two parts: the northern state, ruled by Henry Christophe, and the south and west area which was ruled by Alexandre Pétion, both of whom were generals in the Haitian revolution's army. This geographical division constituted the new political and economic configuration of Haiti. The period of 1806-20 is considered as a transitional and founding era of the nation (Hector 2009:243), with the two political regions governed by different political ideologies. In the north, Christophe established a kingdom in 1811 and retained the plantation system for the large-scale export of products (Fick 2000:31), while in the south, Pétion distributed land to soldiers and farmers, effectively constituting the end of the plantation system.

During the revolutionary war many plantations were destroyed, although some places previously inhabited by masters and gens de couleur were consequently reappropriated by formerly enslaved people. For instance, in the north, Christophe continued large landholdings, granting concessions of between 50-60 ha to his nobles (Moral 1961:29, cited in Lacerte 1978:356). This particular time was important in the process of landscape reorganization, to such an extent that former plantations were reused for the perpetuation of the new economy with a kind of de facto recreation of a plantation system. The Kingdom of Christophe encouraged trade, especially with Great Britain (Fick 2000:32; Garraway 2012). British merchants established ties with the Republic of Haiti and the economic connection continued after the independence (McIntosh and Pierrot 2017:127-142).

In his work upon the Fort-Liberté region, Jean (2019) highlights how the French colonial landscape was organized through establishing large-scale colonial plantations, where arid zones were mainly used for indigo, while semi-arid and alluvial areas were dedicated to sugar cane. Jean (2019:114-132) also reveals that many utilitarian goods from Europe were transported to and within the region as is evidenced by different types of eighteenth-century ceramics. Monroe (2017:5-6) studied changes in the process of the construction of Haitian political identities that occurred after the Haitian independence during the period of Christophe's Kingdom. Archaeological data revealed that during Christophe's reign goods were acquired from long-distance trade networks, where Great Britain and the United States played important roles in animating palace spaces and promulgating royal power and status in Christophe's Haiti (Monroe 2017:22).

\section{The import of ceramics at Fort Liberté}

In the current research, the focus is on the region of Fort Liberté, located in northeastern Haiti near the border with the Dominican Republic, which was part of Christophe's Kingdom (see Fig. 1) in the first half of the nineteenth century. The area yields archaeological material from different historical and cultural origins such as pre- 
Columbian, Spanish, French, and after 1804, of Haitian provenance (Jean 2019:1-17), showing continuity in the use of the landscape. Surveys in both urban and rural areas, such as former plantations and pasture lands, identified numerous imported ceramics dated between the eighteenth and the beginning of the nineteenth century, mainly of southern French origin (terre cuite verte, faïence blanche, faïence brune, ceramics from Saintonge, Biot, and the Huveaune valley) and in smaller quantities wares attributable to other European, in particular English pearlware (dated to the early nineteenth century) and Italian production centers (Fig. 2). These findings show a clear connection between the French markets and the landowners of the colony of Saint-Domingue, for whom the European ceramics were mainly exported. Enslaved people, in contrast to their masters, were not active participants in market choices, and commonly used locally handmade ceramics which were generally undecorated. Those local productions played an important role in the local Black markets (e.g., Armstrong 2003; Armstrong and Fleischman 2003; Armstrong and Hauser 2009; Armstrong and Kelly 2000; Delle 1999; Hauser 2008, 2011; Haviser 1999; Wilkie and Farnsworth 1999, 2005). The presence of British pearlwares, however, showed how the political changes that occurred after independence affected the importation of goods on the island, with new international products flowing into the Haitian market.

The taches noires ware is particularly common in several archaeological contexts of Fort Liberté (Jean 2019:139-140) and Sans-Souci (J. C. Monroe, pers. comm. 2020), as in other areas of the Americas (Amouric et al. 2016:103-106). Due to the continued production of the taches noires, which encompasses the time before and after independence, a thorough analysis of how the diffusion and appreciation of this ceramic style developed in the newborn Haitian Republic

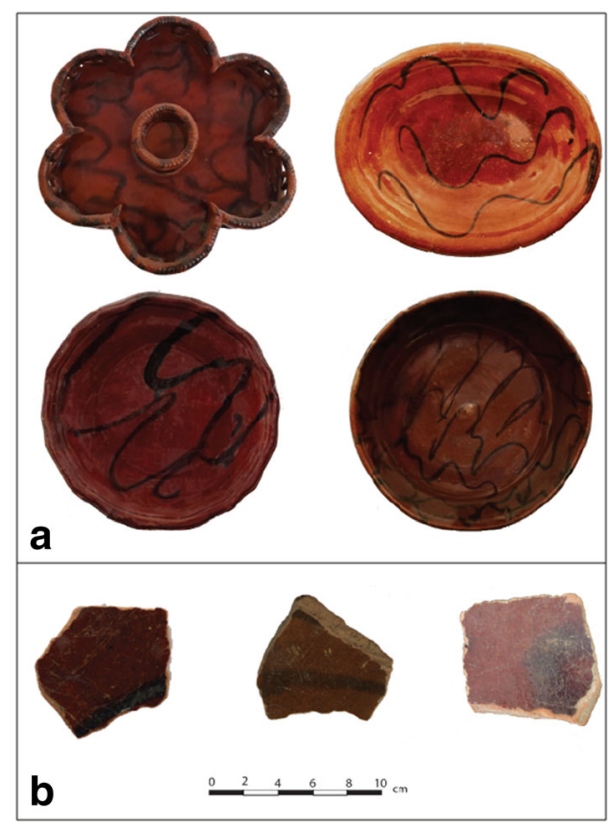

Fig. 2 (a) Taches noires plates from Albisola (Patrone's private collections, Genoa and Savona, Italy) (not scaled). At the bottom, (b) three fragments of taches noires retrieved in Fort Liberté and analyzed in this study 
can provide crucial insights into social awareness and elements of continuity and discontinuity between the prior French plantation-based society and the new Republic made up of previously enslaved peoples. The results add new knowledge on this contested historical period in Haiti, with a particular focus on the region of Fort Liberté.

\section{The taches noires ware}

At the beginning of the eighteenth century, the important pottery center of Albisola (Liguria, northwestern Italy) started the production of one of the most successfully globally exported ceramics, taches noires glazed ware (Cameirana 1980:277-293), mostly consisting of plates, bowls, and to a lesser extent, cooking wares. This new product was fired in saggars in two stages under oxidizing conditions, and is characterized by a brown-reddish body, with a fine and hard clay matrix (derived from the mixing of alluvial and marine clays) and a bright yellow high lead, iron-rich glaze, and abstract decoration painted with informal lines and spots (taches in French) based on manganese oxides (Fig. 2) (Capelli et al. 2017; Chabrol de Volvic 1824).

A great advantage of the taches noires was a high resistance to heat and impact at a considerably low cost, together with a great aesthetic innovation from the earlier Ligurian majolica, that was another successful production from Albisola (Capelli and Cabella 2015:27-36). Due to these features and the skill of Ligurian merchants, this ceramic quickly spread into the western Mediterranean and consequently reached the Americas through Spanish and French traders. The use of this type of ceramic is well documented in Canada, Mexico, and in the Caribbean region (Amouric et al. 2016:103106).

During the eighteenth century, due to the high demand of the taches noires, several workshops from southern France and Spain started producing lowerquality imitations, yet these productions did not match the success of Ligurian ware. In fact, analyses showed no technological link of these early imitations with the original products. Both the body and glaze compositions, together with manufacturing practices, are very different from Albisola products (Capelli et al. 2017; Di Febo et al. 2018). However, in the early nineteenth century, the production in Albisola collapsed due to the imposition of import duties by the Spanish (1809) and French (1820) governments in order to promote their local manufacturers. Consequently, Albisola potters migrated and started new production centers, transferring their knowledge, in either Provence (France) or Barcelona (Spain), which continued until the middle of the nineteenth century. Although these later productions were very similar to the original ware in typology and technology, recent archaeometric analyses distinguished the composition of the paste and glaze, which clarified the provenance of these ceramics (Capelli et al. 2017; Di Febo et al. 2018).

At the moment, taches noires wares that are recovered in Haiti are generally labelled as Albisola. The aim of this paper is to define a more exact origin of these wares, and to connect them to Italian, French, or Spanish productions. Identifying the provenance can help us to clarify import dates because we have specific temporal markers connected with the French and Spanish duties on Albisola. 


\section{Materials and Methods}

For this analysis, the sample selection consists of 30 sherds. Fifteen specimens belong to archaeological research at Fort Liberté (Jean 2019) and 15 sherds were selected as reference samples from archaeological excavations in Albissola.

This region of Fort-Liberté is a flat area characterized by dry and watered sectors that were suitable for implementation of both indigo and sugar plantations. Jean (2019) carried out an extensive surface survey in the region of Fort-Liberté. The results of this regional survey allowed documenting different types of colonial archaeological traces, such as military fortresses, ruins of plantations, and colonial houses, and highlighting the configuration of the Fort-Liberté's rural colonial landscape. Around thousands of different colonial ceramics mainly from France associated with other ceramics from England, Germany, and Italy have been documented.

Macroscopy analysis of the ceramic materials identified taches noires vessels across the entire analyzed area (Jean 2019:139-140). A careful selection for further archaeometric analysis was made through the assemblage in order to avoid selecting sherds from the same vessels and to cover the region extensively. It resulted in a selection of 15 taches noires sherds from different areas along the coast and the hinterlands: former plantations, military fortress, and rural environments. (see Fig. 1 for the find locations of the fragments in the region of Fort Liberté).

In 1800, in Albissola were documented about 50 active ceramic workshops (Restagno 1976:351-384), with an estimated production of 20 million pieces per year (Cameirana 1980). Previous archaeological and archaeometrical studies established that generally taches noires wares produced in Albissola are morphological, stylistically, and compositionally homogeneous, without major differences that could lead to establish a specific workshop production (Capelli et al. 2017; Chabrol De Volvic 1824). The selected Albisola samples are considered to be kiln wasters dating to the eighteenth early nineteenth centuries. The samples are misfired objects. Items that broke during the firing and/or present the surface with imperfections, incomplete, and unglazed parts. These kiln wasters are commonly found in Albissola and provide a reliable source of information related to the composition of the paste and/or glaze because of their visible imperfection, potters did not sell but discarded them right after taking them out of the kiln. This action significantly reduces the risk of analyzing an imported object. In order to get a broader spectrum of the production, the selected samples were chosen between archaeological excavations carried out by the Ligurian archaeological superintendence, in two different areas: Albisola Superiore (Piazza Giulio II and San Pietro) and in Albissola Marina (Via Isola) (Annetta and Bulgarelli 2001; Bulgarelli and Geltrudini 2013).

Geochemical analyses are well established to characterize and distinguish the composition of archaeological ceramics. This research selected inductively coupled plasma with optical emission spectrometry (ICP-OES) and scanning electron microscope with energy dispersive spectroscopy (SEM-EDS), which have proven to provide precise and accurate compositional results for both the paste and glaze of earthenwares. Both techniques are able to separate production areas or to distinguish the use of different raw materials (such as clay) or between different recipes (Finlay et al. 2012; Glascock et al. 1994; Gratuze 1999; Sharrat et al. 2009). The aim here is to compare the compositions of the Haitian samples with the productions of taches noires on Albisola, 
France, and Spain to reconstruct the artisanal and trade activities related to this unique type of ceramics. Table 1 presents an overview of the samples with locations, vessel's part, state of the samples, and the type of analysis that was carried out.

Table 1. Samples overview with locations

\begin{tabular}{|c|c|c|c|c|c|c|c|}
\hline $\begin{array}{l}\text { S a mple } \\
\text { code }\end{array}$ & Provenance & $\begin{array}{l}\text { Vessel } \\
\text { part }\end{array}$ & $\begin{array}{l}\text { Glazed/ } \\
\text { unglazed }\end{array}$ & Petrography & $\begin{array}{l}\text { IC P - } \\
\text { OES }\end{array}$ & $\begin{array}{l}\text { SEM-EDS } \\
\text { body }\end{array}$ & $\begin{array}{l}\text { SEM-EDS } \\
\text { Glaze }\end{array}$ \\
\hline $1079-21$ & Giulio II (Albissola) & body & unglazed & yes & yes & no & no \\
\hline $1079-23$ & Giulio II (Albissola) & body & unglazed & yes & yes & yes & no \\
\hline $1079-25$ & Giulio II (Albissola) & body & glazed & yes & yes & yes & yes \\
\hline $1079-26$ & Giulio II (Albissola) & body & unglazed & yes & yes & yes & no \\
\hline $1079-27$ & Giulio II (Albissola) & body & unglazed & yes & yes & no & no \\
\hline $1079-29$ & Giulio II (Albissola) & body & unglazed & Yes & yes & no & no \\
\hline $1079-30$ & Giulio II (Albissola) & body & unglazed & yes & yes & no & no \\
\hline $1079-33$ & Giulio II (Albissola) & body & glazed & yes & yes & yes & yes \\
\hline $1079-34$ & Giulio II (Albissola) & body & glazed & yes & yes & yes & no \\
\hline $1079-35$ & Asilo Balbi (Albissola) & body & unglazed & yes & yes & no & no \\
\hline $1079-37$ & $\begin{array}{l}\text { Via San Pietro } \\
\text { (Albissola) }\end{array}$ & body & unglazed & yes & yes & yes & no \\
\hline $1079-40$ & $\begin{array}{l}\text { Via San Pietro } \\
\text { (Albissola) }\end{array}$ & body & glazed & yes & yes & no & no \\
\hline $1079-43$ & Via Isola (Albissola) & body & glazed & yes & yes & no & yes \\
\hline $1079-44$ & $\begin{array}{l}\text { Albissola Marina } 07 \\
\quad \text { (Albissola) }\end{array}$ & body & unglazed & yes & yes & no & no \\
\hline BY-91 & Haiti/Plantation & body & glazed & yes & yes & yes & yes \\
\hline BY-95-1 & Haiti/Plantation & body & glazed & yes & yes & yes & no \\
\hline BY-95-2 & Haiti/Plantation & body & glazed & yes & yes & yes & yes \\
\hline MR-142-1 & Haiti/Plantation & body & glazed & yes & yes & yes & no \\
\hline MR-142-2 & $\begin{array}{c}\text { Haiti/Coastline } \\
\text { settlement }\end{array}$ & body & glazed & yes & yes & yes & no \\
\hline GD-316-1 & $\begin{array}{c}\text { Haiti/Coastline } \\
\text { settlement }\end{array}$ & body & glazed & yes & yes & yes & yes \\
\hline GD-316-2 & $\begin{array}{c}\text { Haiti/Coastline } \\
\text { settlement }\end{array}$ & body & glazed & yes & yes & yes & yes \\
\hline CP-253-1 & $\begin{array}{c}\text { Haiti/Coastline } \\
\text { settlement }\end{array}$ & body & glazed & yes & yes & yes & yes \\
\hline CP-253-2 & $\begin{array}{c}\text { Haiti/Coastline } \\
\text { settlement }\end{array}$ & body & glazed & yes & yes & yes & yes \\
\hline ZL-31-1 & Military area & body & glazed & yes & yes & yes & yes \\
\hline Zl-31-2 & Military area & body & glazed & no & no & yes & yes \\
\hline ZL-31-3 & Military area & body & glazed & yes & yes & yes & yes \\
\hline CL-131 & Urban area & body & glazed & yes & yes & yes & yes \\
\hline JG-1 & Urban area & body & glazed & yes & yes & yes & yes \\
\hline AG-250 & Urban area & body & glazed & yes & yes & yes & no \\
\hline
\end{tabular}


Thin section petrography $(n=29)$ was selected to gain further technological and mineralogical-petrographic information. This allows a characterization of the paste, and the identification of various mineral and rock inclusions. The interpretation of textural information can moreover clarify the technological choices involved in the manufacturing process (Quinn 2013; Rice 1987; Whitbread 1986). Thin sections were prepared at the Division of Geology of KU Leuven and studied under plane and crossed polarized light using a Olympus BX41 polarizing microscope at the DISTAV archaeometry lab (University of Genoa).

Chemical analyses of ceramics and glazes were carried out by means of a variable pressure scanning electron microscope coupled with energy-dispersive X-ray spectroscopy (VP-SEM-EDS) at Cranfield University, and by means of a Varian inductively coupled plasma optical emission spectroscopy at KU Leuven. For the SEM-EDS investigation, samples were embedded in epoxy resin and polished prior to analysis. The instrument was operated at $20 \mathrm{kV}$, with a measuring time of $100 \mathrm{~s}$. The analytical equipment consisted of a Hitachi SU3500 variable pressure SEM-EDS providing semiquantitative results. Both fabric and glaze were analyzed for each sample in three different locations with area analysis and the results were averaged as data treatment. Selection of analysis locations was based on avoiding large inclusions, weathered or contaminated surface layers, and glaze body interfaces that might influence the composition. Analytical precision was checked through routine analysis of external standards, applying a ZAF quantification (Reed 2005).

ICP-OES was used to characterize the bulk geochemical composition of the ceramic materials while SEM-EDS provided analysis to chemically characterize the different components of the ceramics, with a separate focus on ceramic matrix and glaze. The ICP-OES analyses were carried out at the Division of Geology (KU Leuven) using the complete sample. Samples were powdered using a planetary ball mill. Quality control was monitored using international standards such as PRI1, GBW 7411, BCS 267, BCS 269, NIST 610, NIST 2782. Major oxides $\left(\mathrm{Al}_{2} \mathrm{O}_{3}, \mathrm{CaO}, \mathrm{Fe}_{2} \mathrm{O}_{3}, \mathrm{~K}_{2} \mathrm{O}, \mathrm{MgO}, \mathrm{Na}_{2} \mathrm{O}, \mathrm{P}_{2} \mathrm{O}_{5}, \mathrm{SiO}_{2}\right.$, and $\left.\mathrm{TiO}_{2}\right)$ and trace elements (Ba, $\mathrm{Cr}, \mathrm{Cu}, \mathrm{Mn}, \mathrm{Ni}, \mathrm{Pb}, \mathrm{Rb}, \mathrm{Sc}, \mathrm{Sr}, \mathrm{V}, \mathrm{Y}, \mathrm{Zn}$, and $\mathrm{Zr}$ ) were measured.

It should be noted that due to the small size of the samples it was not always possible to completely remove the glaze from the body prior to analysis. Next to mineralogical data obtained through petrographic analysis and the analysis of the glaze surface (SEMEDS), the ICP-OES data represents here the bulk geochemistry of the entire sherd, bearing in mind that some elements, such as iron and lead, can be respectively present in both substrate and glaze (iron), or mainly glaze only (lead), possibly influencing the interpretation of the bulk chemistry of samples. However, nine of the 14 Albisola ceramic samples did not have a layer of glaze (which was missed as they are misfired items with imperfections and discarded by potters) and thus can be regarded as being representative of the ceramic fabric.

\section{Results}

\section{Petrographic analysis}

Under the polarizing microscope and the SEM, all samples (both Albisola wasters and Haitian finds) form a homogeneous group. The body fabric is characterized by an 
oxidized iron-rich clay matrix (with a subordinate calcareous component) with abundant and fine-grained inclusions (generally $<0.2 \mathrm{~mm}$ ), mainly consisting of elements derived from acidic metamorphic rocks (quartz, mica, feldspar, rare gneiss fragments), calcareous microfossils (foraminifera, rare echinoid radiols), smaller amounts of siliceous microfossils (sponge spiculae, diatoms, radiolarians), amphibole (hornblende), epidote, and, occasionally other heavy minerals (garnet, tourmaline, opaque minerals) and metabasite (plagioclase amphibolite) fragments. There is also evidence of two different interference colors in the body under crosses polarization, that can be related to the mixing of two different clays, as recorded in the historical documents (Chabrol de Volvic 1824) but an uneven firing process might generate multiple colors in the matrix as well.

The glaze (in some cases absent from single-fired kiln wasters) is transparent and yellow under plane polarized light and shows a homogeneously fine thickness (generally $<0.2 \mathrm{~mm}$ ). Generally, the glaze thickness for the samples from Albisola varies between 75 to $200 \mu \mathrm{m}$. For the Haitian samples, the glaze thickness varies from 150 to $200 \mu \mathrm{m}$, the only exception being sample CP253-2, which has a glaze up to $330 \mu \mathrm{m}$ (Fig. 3).

\section{Chemical analysis}

The combination of the SEM-EDS $(n=21)$ and ICP-OES $(n=30)$ generally confirms the petrographic observations, pointing to an unique origin from Albisola for the taches
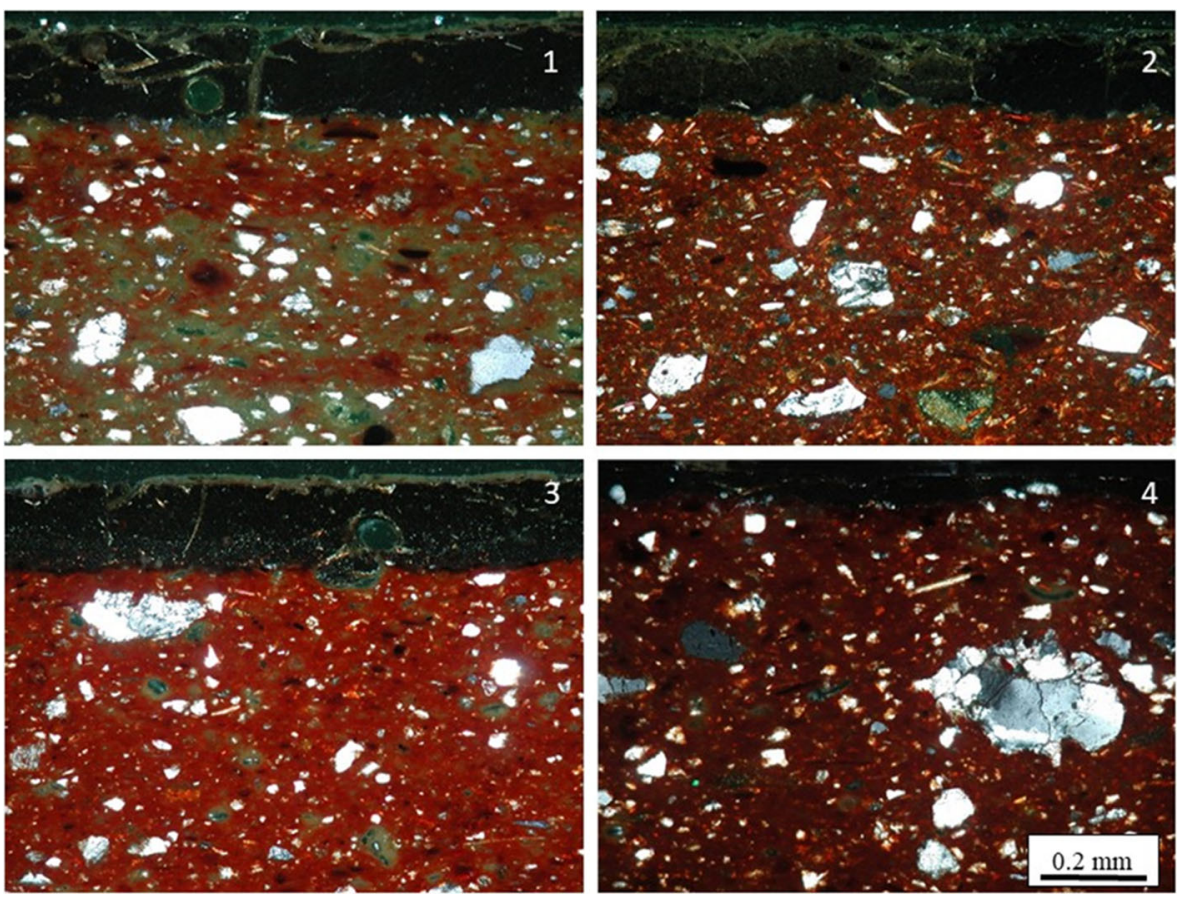

Fig. 3 Photomicrographs of [1, 2] samples from Albisola; [3, 4] samples from Haiti. Images taken with crosspolarized light 
noires wares recovered in Haiti. The minor variability evidenced by both Haitian and Albisola groups is in agreement with the differences in the percentages of inclusions and of the carbonate component of the clay observed under the microscope.

To validate the data, results have been compared with the previously compositional studies on taches noires produced in Barcelona (Di Febo et al. 2018:9-10) and in Provence (Capelli et al. 2017:343) by means of SEM-EDS. The results are presented in Tables 2, 3, and 4 respectively.

\section{ICP-OES}

The chemical analysis of the paste gave similar results to the petrographic observations, showing correspondence between the Haitian specimens and the Ligurian reference fragments. It can be noted in some cases the presence of a relatively high lead contents $(>30000 \mu \mathrm{g} / \mathrm{g}$ ) attributable to parts of glaze that were not completely removed, as well as from the outer part of the body that interacted with the glaze, which is confirmed by the very low lead values $(<400 \mu \mathrm{g} / \mathrm{g})$ in unglazed single-fired Albisola wasters. However, we recalculated the element values without the lead oxide and the results demonstrate that the other elements do not seem to be significantly affected by the presence of glaze. The biplots show the variations of some trace elements, such as $\mathrm{Y}$ and $\mathrm{Zr}$, and $\mathrm{Ni}$ and $\mathrm{Cr}$ (Figs. 4, 5, and 6), indicating a clear overlap in the compositions between the Haitian and Ligurian reference specimens (ALB). This result confirms the use of the same raw materials for manufacturing body and glaze for both sites.

\section{SEM-EDS}

Body SEM-EDS analysis on the ceramic bodies were carried out in addition to the high resolution ICP-OES measurements in order to directly validate and compare these results with the published data of taches noires productions from Albisola, Barcelona, and Provence (Capelli et al. 2017:343; Di Febo et al. 2018:9-11). In order to allow the comparison of compositional results obtained from different SEM-EDS systems, the oxides values were recalculated to $100 \%$ for $\mathrm{Na}_{2} \mathrm{O}, \mathrm{MgO}, \mathrm{Al}_{2} \mathrm{O}_{3} . \mathrm{SiO}_{2}, \mathrm{~K}_{2} \mathrm{O}, \mathrm{CaO}$, $\mathrm{Ti}_{2} \mathrm{O}, \mathrm{MnO}, \mathrm{Fe}_{2} \mathrm{O}_{3}$ and the ratio of the oxides is subsequently used. A high level of similarity exists between the groups from Haiti and Albisola (ALB). The limited differences, similarly to the ICP-OES data, can be attributed to variations in the calcareous component in the clay matrix and in the relative and absolute percentages of the inclusions. In particular, the calcium content varies between 3.1-10.6 $\mathrm{CaO} \%$ for the Albisola group, while the Haitian samples yield a slightly wider range 3.0-14.8 $\mathrm{CaO} \%$, which can be related to a higher presence of calcareous component in the clay evidenced by shell microfossil and carbonate-rich nodules that were identified in the petrographic observations. Magnesium shows a slight positive correlation with calcium, possibly related to a dolomitic component in the clayey materials. Two subgroups, with few outliers, can be distinguished with higher or lower magnesia contents.

The Haiti and Albisola reference groups (ABL, TN1) similarly diverge from groups TN2 and TN3 (Barcelona) (Di Febo et al. 2018), showing a different ratio of $\mathrm{MgO}$ / $\mathrm{CaO}$. There is only one sample ZL-31-3 which shows a low value in magnesia, however, the general composition of the matrix is similar to the rest of the Albisola samples. TN3 in particular has lower values of magnesia, while TN2 yields a lime-poor 


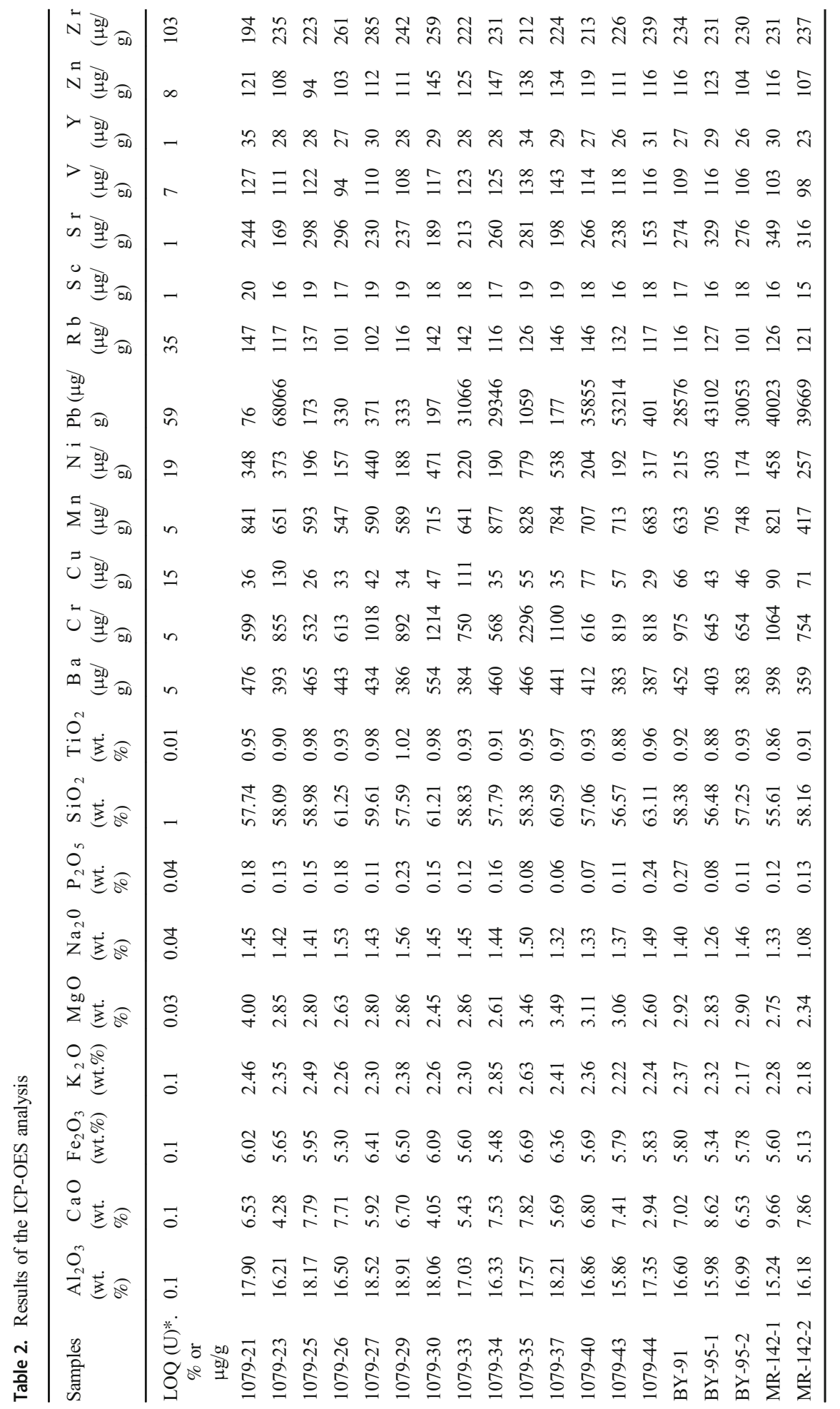




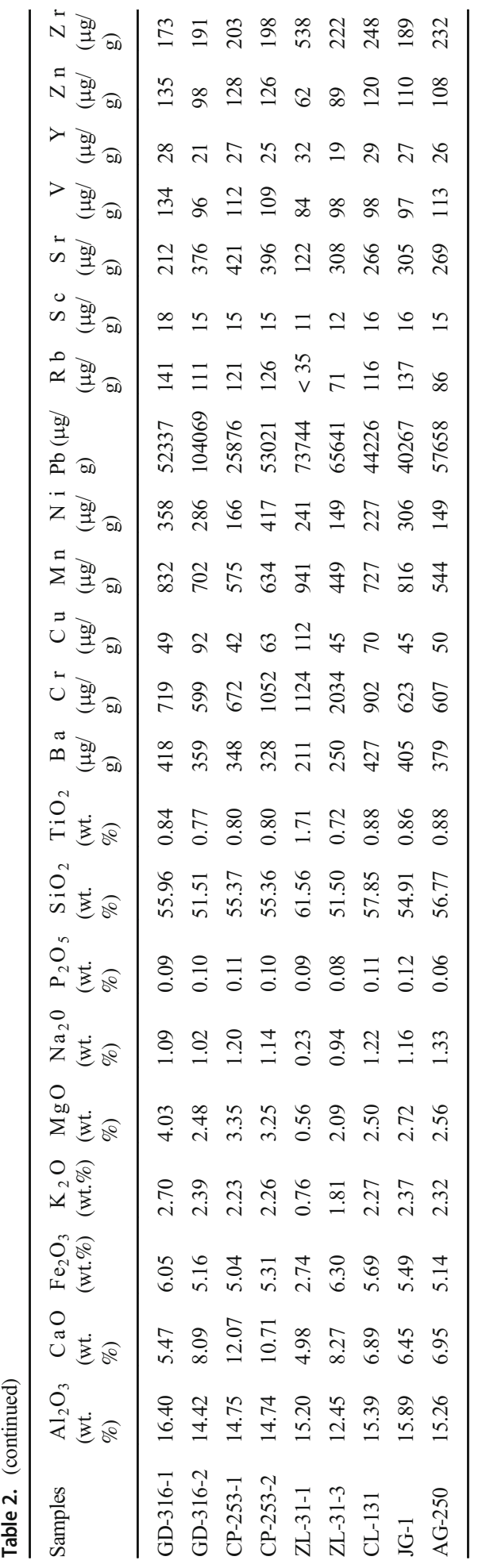




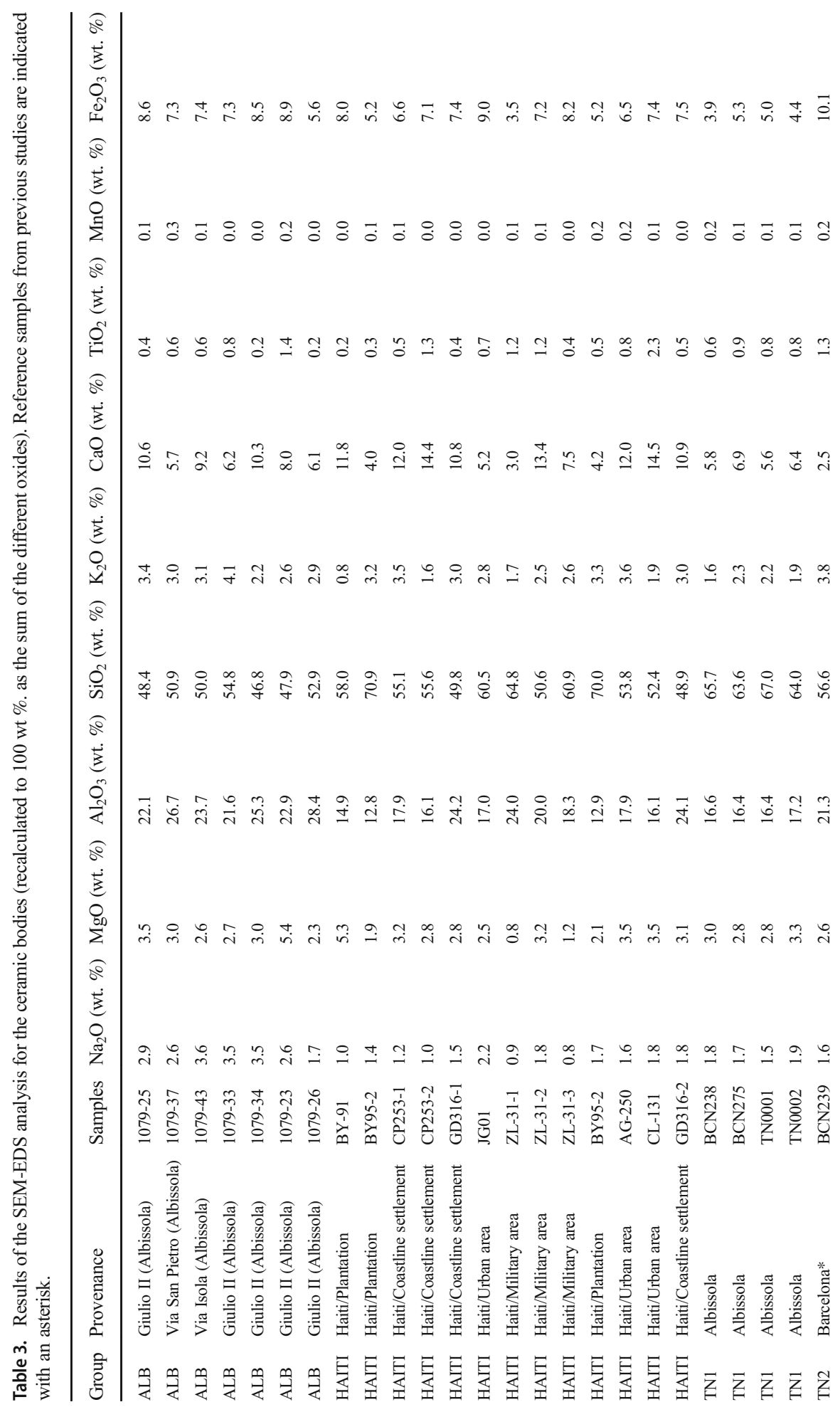




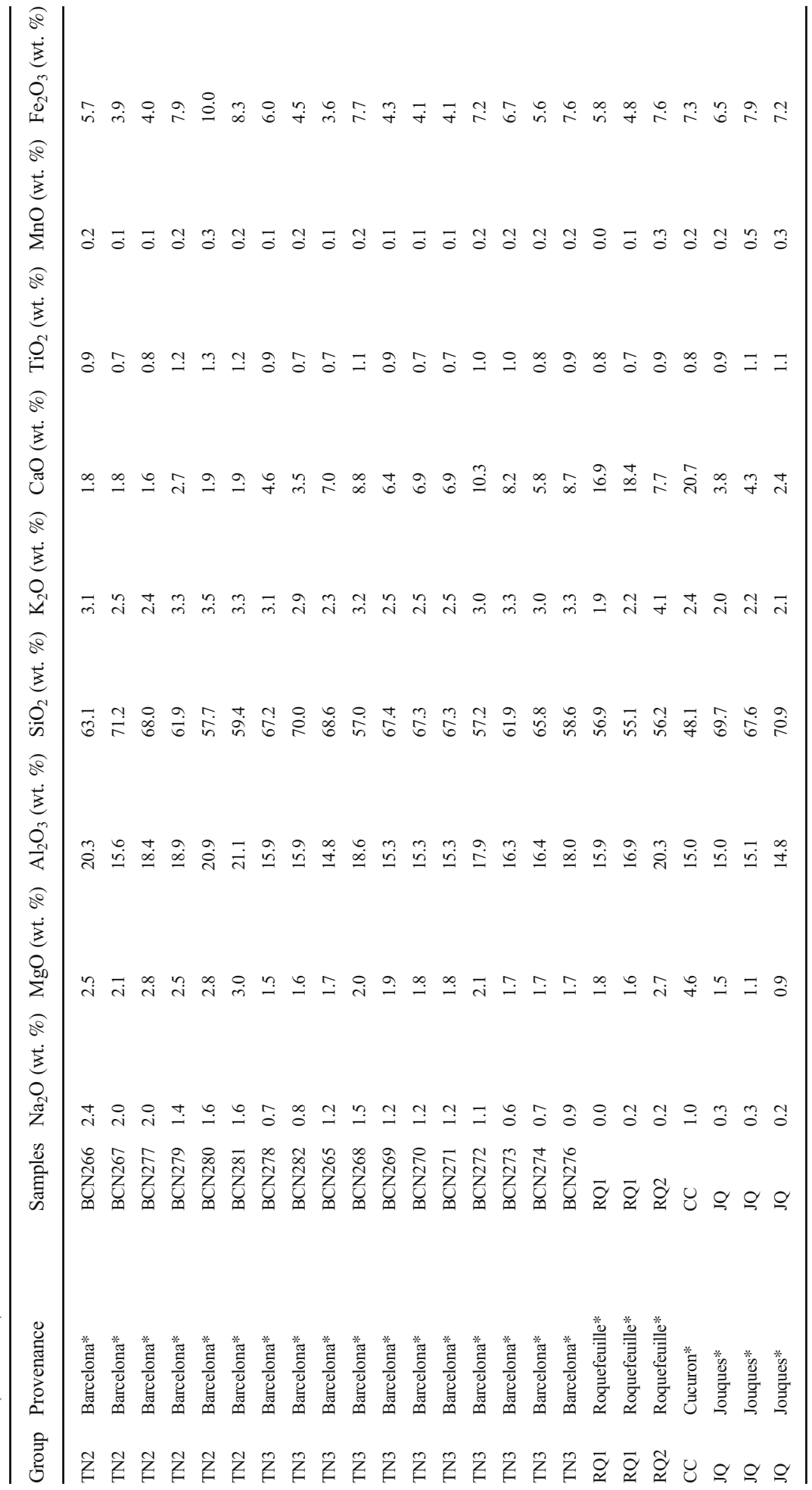


Table 4. Results of the SEM-EDS analysis for the ceramic glazes (recalculated to $100 \mathrm{wt} \%$. as the sum of the different oxides). Reference samples from previous studies are indicated with an asterisk. RQ: Roquefeuille, CC:Cucuron, JQ: Jouques

\begin{tabular}{|c|c|c|c|c|c|c|c|c|c|c|c|}
\hline Group & Samples & $\begin{array}{l}\mathrm{Na}_{2} \mathrm{O} \\
\text { (wt. } \\
\% \text { ) }\end{array}$ & $\begin{array}{l}\text { MgO } \\
\text { (wt. } \\
\% \text { ) }\end{array}$ & $\begin{array}{l}\mathrm{Al}_{2} \mathrm{O}_{3} \\
\text { (wt. \%) }\end{array}$ & $\begin{array}{l}\mathrm{SiO}_{2} \\
\text { (wt. } \\
\% \text { ) }\end{array}$ & $\begin{array}{l}\mathrm{PbO}_{2} \\
\text { (wt. } \\
\% \text { ) }\end{array}$ & $\begin{array}{l}\mathrm{K}_{2} \mathrm{O} \\
\text { (wt. } \\
\% \text { ) }\end{array}$ & $\begin{array}{l}\mathrm{CaO} \\
\text { (wt. } \\
\%)\end{array}$ & $\begin{array}{l}\mathrm{TiO}_{2} \\
\text { (wt. } \\
\%)\end{array}$ & $\begin{array}{l}\text { MnO } \\
\text { (wt. } \\
\% \text { ) }\end{array}$ & $\begin{array}{l}\mathrm{Fe}_{2} \mathrm{O}_{3} \\
\text { (wt. \%) }\end{array}$ \\
\hline ALB & $1079-23$ & 0.7 & 0.9 & 5.5 & 42.9 & 42.4 & 0.9 & 1.2 & 0.0 & 0.0 & 5.3 \\
\hline ALB & $1079-33$ & 0.8 & 1.3 & 9.4 & 45.9 & 30.5 & 1.7 & 3.1 & 0.4 & 0.6 & 5.9 \\
\hline ALB & $1079-43$ & 0.8 & 0.9 & 7.1 & 45.9 & 31.5 & 1.4 & 3.0 & 0.5 & 0.6 & 8.1 \\
\hline HAITI & CP253-1 & 0.2 & 0.2 & 2.6 & 39.5 & 49.3 & 0.5 & 1.1 & 0.0 & 0.2 & 6.3 \\
\hline HAITI & ZL-31-1 & 0.3 & 0.0 & 4.3 & 42.4 & 46.8 & 1.4 & 1.5 & 0.2 & 0.7 & 1.8 \\
\hline HAITI & CP253-2 & 0.2 & 0.3 & 3.5 & 38.3 & 46.0 & 0.7 & 2.4 & 0.3 & 0.2 & 8.1 \\
\hline HAITI & CL131 & 0.3 & 1.2 & 7.8 & 41.5 & 33.4 & 1.2 & 4.6 & 0.5 & 0.5 & 8.1 \\
\hline HAITI & GD316-2 & 0.5 & 0.2 & 3.8 & 35.8 & 44.3 & 0.9 & 1.4 & 0.5 & 1.2 & 11.4 \\
\hline HAITI & JG01 & 0.0 & 0.0 & 2.7 & 36.4 & 53.3 & 0.3 & 0.6 & 0.0 & 0.4 & 5.9 \\
\hline HAITI & GD316-1 & 0.4 & 0.6 & 5.8 & 38.3 & 38.4 & 0.9 & 3.0 & 0.4 & 0.9 & 9.5 \\
\hline HAITI & BY95-2 & 0.5 & 0.5 & 5.6 & 36.3 & 45.5 & 1.0 & 2.8 & 0.5 & 0.3 & 7.0 \\
\hline HAITI & BY-91 & 0.0 & 0.0 & 2.5 & 39.8 & 47.5 & 0.4 & 1.2 & 0.1 & 0.2 & 8.0 \\
\hline HAITI & ZL-31-2 & 0.4 & 0.3 & 3.6 & 38.5 & 46.7 & 0.7 & 1.8 & 0.0 & 1.3 & 6.6 \\
\hline RQ* & 9612 & 0.1 & 0.6 & 7.0 & 29.4 & 58.0 & 0.6 & 1.3 & 0.4 & 0.4 & 2.2 \\
\hline RQ* & 9613 & 0.2 & 0.3 & 5.7 & 30.1 & 59.5 & 0.5 & 1.1 & 0.4 & 0.2 & 2.0 \\
\hline RQ* & 9614 & 0.3 & 0.5 & 5.5 & 28.1 & 63.2 & 0.2 & 0.2 & 0.4 & 0.2 & 1.3 \\
\hline $\mathrm{CC}^{*}$ & 9981 & 0.0 & 0.5 & 6.1 & 36.2 & 51.5 & 0.3 & 2.3 & 0.8 & 0.0 & 2.3 \\
\hline JQ* & 9703 & 0.0 & 0.3 & 2.9 & 35.2 & 55.9 & 0.2 & 0.7 & 0.0 & 0.0 & 4.8 \\
\hline JQ* & 9707 & 0.0 & 0.2 & 2.1 & 32.4 & 59.8 & 0.0 & 0.5 & 0.7 & 0.2 & 4.0 \\
\hline $\mathrm{JQ}^{*}$ & 9708 & 0.0 & 0.5 & 3.6 & 35.5 & 51.7 & 0.2 & 1.2 & 0.6 & 1.5 & 5.1 \\
\hline
\end{tabular}

matrix $(+/-<5 \%)$, which indicates the use of different clay sources from the production in Albisola. The French samples from Roquefeuille (RQ1) and Cucuron (CC) diverge
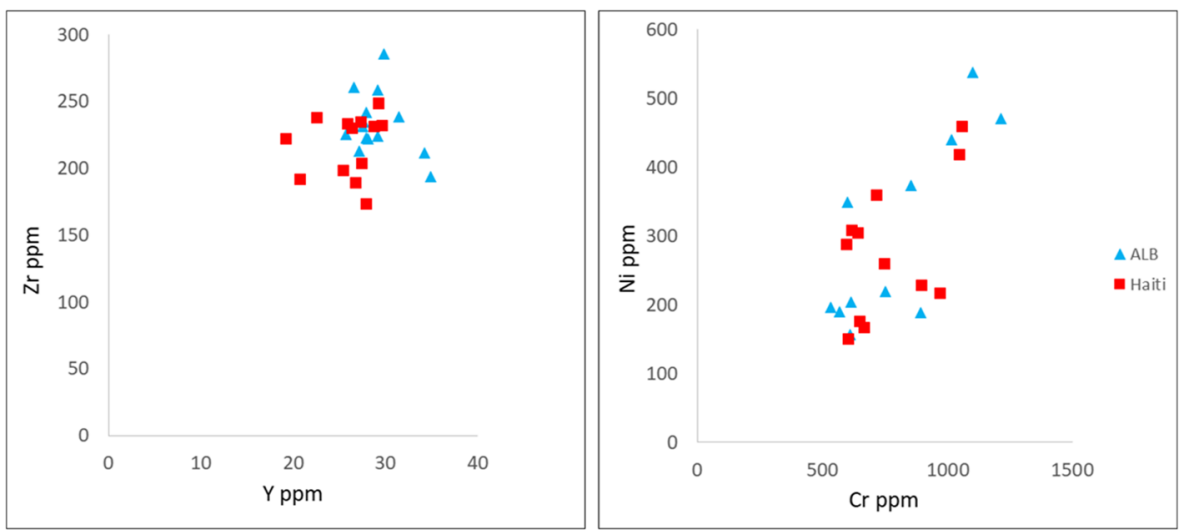

Fig. 4 Body chemical composition from ICP-OES analysis. Biplots of Zr vs Y (ppm) and Ni vs Cr (ppm) of the taches noires retrieved in Haiti and the reference samples from Albisola 


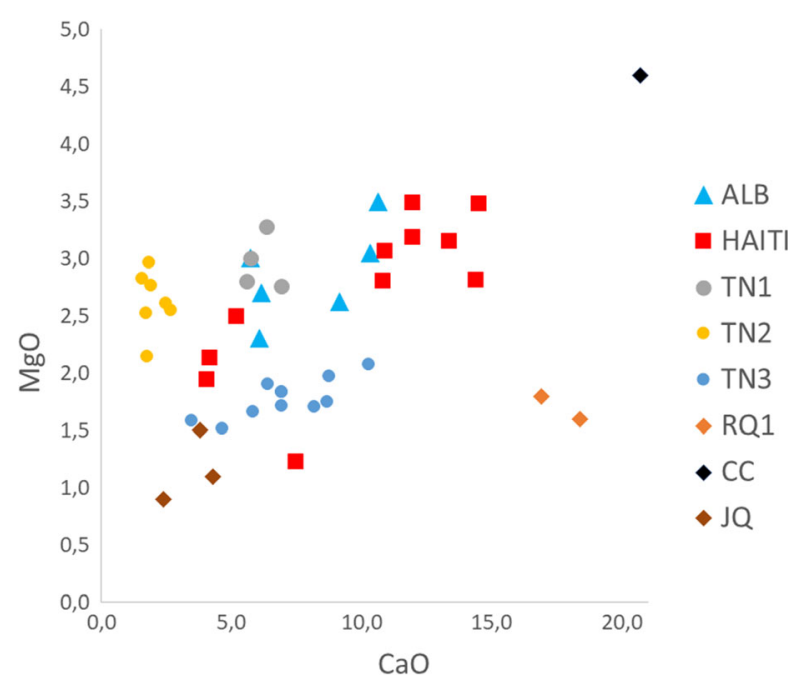

Fig. 5 SEM-EDS analysis of the ceramic materials. Biplot of $\mathrm{CaO}(\mathrm{wt} \%)$ and $\mathrm{MgO}(\mathrm{wt} \%)$ for the taches noires wares retrieved in Haiti and the reference samples from Albisola (ALB and TN1) and the previous analysis of taches noires ware from Barcelona (TN2 and TN3) (Di Febo et al. 2018) and production from Provence: Roquefeuille (RQ1), Cucuron (CC) and Jouques (JQ) (Capelli et al. 2017)

substantially, showing a lime-rich matrix, while Jouques (JQ) yields lower values in lime and magnesia.

Glaze Glaze analyses were performed on seven samples from Haiti and four specimens from Albisola, where the glaze was well preserved. Both Haitian and

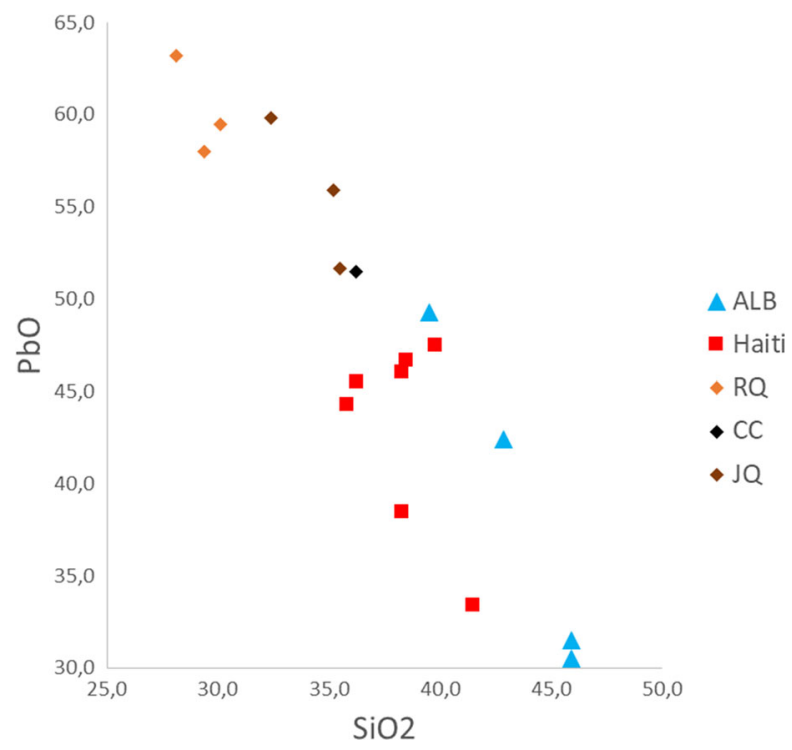

Fig. 6 Glaze chemical composition from SEM-EDS analysis. Biplot of $\mathrm{SiO}_{2}(\mathrm{wt} \%)$ and $\mathrm{PbO}(\mathrm{wt} \%$ ) of the glaze of taches noires wares retrieved in Haiti and the reference samples from Albisola (ALB) and samples from Provence: Roquefeuille (RQ), Cucuron (CC) and Jouques (JQ) analysed by Capelli et al. (2017) 
Albissolan groups are characterized by a relatively high iron glaze, with less content of lead in contrast with the taches noires from France. Table 4 shows oxide values for the glaze of each group together with the results of Capelli et al. (2017) for the samples from Provence. In particular, they have similar quantities of lead (30.0-42.4 $\mathrm{PbO} \%$ Albisola; 33.4-49.3 $\mathrm{PbO} \%$ Haiti) and silica (42.9- 45.9 $\mathrm{SiO}_{2} \%$ Albisola, 35.8-42.4 $\mathrm{SiO}_{2} \%$ Haiti), in contrast with $\mathrm{RQ}, \mathrm{CC}$ and JQ samples, which have a higher lead average $(\mathrm{PbO}>50 \%)$ and a lower silicon content $\left(\mathrm{SiO}_{2}<36 \%\right)$, demonstrating different recipes for the glaze preparation. A comparison of $\mathrm{PbO} / \mathrm{SiO}_{2}$ clearly shows similarities between Haiti and Albisola (ALB) and separates these groups from the French production (RQ, $\mathrm{CC}$, and JQ). Remains of iron-oxides are visibly dispersed in the glaze of some samples (CL-31, CP253-2, and GD316-2) (Fig. 7). Those inclusions, which are common in the Ligurian production (Capelli et al. 2017), are related either to the added coloring agent to obtain the typical yellow (macroscopically brown) glaze or related to the manganese used for paint as mineral impurities.

The regular contact with the ceramic body and the poorly developed glazebody interface (except for overfired kiln wasters) clearly point to a doublefiring process. The presence of rounded, unmelted relict quartz grains, even if exceedingly rare, suggests the direct use of a sand as silicate raw material instead of a frit, as reported by Chabrol de Volvic (1824) and previously identified by Capelli et al. (2017). The black decorations are made with manganese oxides directly on the body before the second firing stage, as shown by a few Albisola unglazed wasters and, occasionally, by fine unmelted grains of the pigment, even if manganese is most frequently dissolved in the glaze which gives it a purple color in plane polarized light.

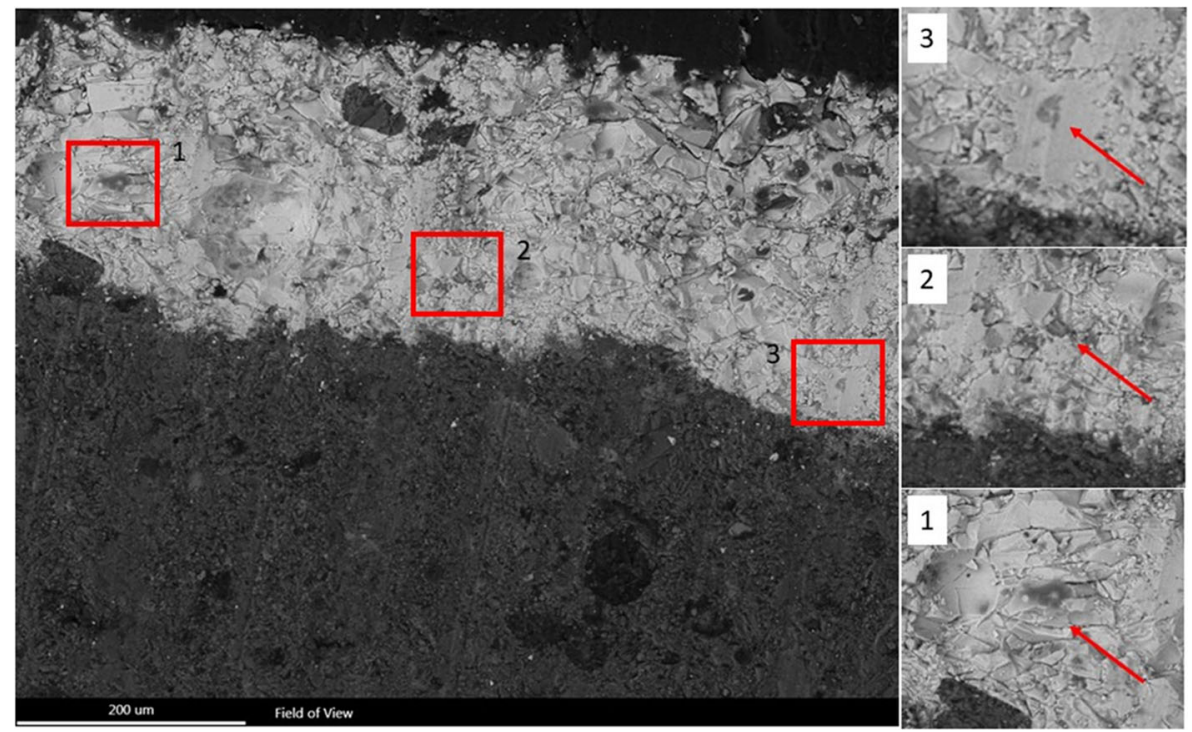

Fig. 7 BSE images of the glaze in sample GD316-2. Relict iron-oxide inclusions, indicated with an arrow, are visibly dispersed in the glaze 


\section{Discussion and conclusion}

Petrographic and chemical analyses of the taches noires wares found in Haiti and the samples from Albisola demonstrate consistent results. Contrastingly, the analysis shows a clear difference between the Haitian samples and other European imitation productions, such as previously studied ones from Barcelona and three different workshops in Provence (Roquefeuille, Cucuron, and Jouques).

All the samples from Haiti are well comparable with Ligurian references for both fabric and glaze, which provides substantial evidence that all the studied Haiti samples come from Albisola. Albisola production is consistently characterized by a unique compositional and technological group, not only composed by the kiln wasters studied here, but also by a number of previously published reference materials (from Albisola, shipwrecks, and consumption sites) (Beltrán de Heredia Bercero et al. 2015:616; Capelli et al. 2013:11-14, 2017:343; Di Febo et al. 2018:9-11). For instance, the double-firing process and evidence of using mananese oxides directly on the body follow the production steps reported by Chabrol de Volvic (1824), who wrote a detailed description of the entire production process for the taches noires manufactured in Albisola when he was prefect of the Dipartimento de Montenotte between 1806-12.

Moreover, the association in the fabrics between metamorphic inclusions (gneiss and amphibolites) related to the local Palaeozoic crystalline basement, altered and deposited in the Quaternary alluvial iron-rich clays, and both calcareous and siliceous microfossils, attributable to the Pliocene marine marls outcropping in the coastal hills, is more generally a strong discriminant marker of the ceramic productions of Albisola and nearby town Savona (Capelli and Cabella 2013:46-47). The chemical analyses of the fabrics confirmed the similarities between the Haiti imports and Albisola references, also evidencing, as discriminant marker the group, high values of some elements (such as chromium and nickel) probably related to both Palaeozoic amphibolites and Jurassic ophiolitic rocks outcropping in the Albisola hinterland (Giammarino et al. 2002).

The fabrics of all the previously studied imitation wares from Provence and Catalonia show clear technological, petrographic and chemical differences with the Ligurian production (Capelli et al. 2017; Di Febo et al. 2018). As for the glaze and decorations, only the later imitations from Jouques show similar recipes to those of Albisola taches noires (Capelli et al. 2017; Chabrol De Volvic 1824), which could point to a direct transfer of knowledge from Liguria. Earlier French wares (from Roquefeuille and Cucuron) are distinguished by uncolored glazes and an iron-rich, red slip put over the light calcareous body to imitate the red-brown macroscopical color of the Ligurian wares.

Although similarity in the composition is clear, both Haiti and Albisola reference samples showed some limited internal group variability in the paste. The production of taches noires extends from the first half of the eighteenth century to the beginning of the nineteenth century. Considering that at the beginning of the 1800 there were 50 documented workshops active in the Albisola area (Restagno 1976:351-384), the slight heterogeneity in composition observed within the samples from Haiti as well as the Albisola reference materials could be easily explained. This compositional variability, however, allows us to hypothesize the arrival of the imported products at different times or from separate Albisola workshops. Moreover, it is likely that the Haitian specimens may not have been produced in the same exact workshops that were tested in this study. 
At the moment, the limited number of samples analyzed versus the tremendous size of the Albissola's production, estimated at 20 million pieces per year around 1800 (Cameirana 1980), does not permit at this point the identification of specific compositional markers of a single workshop, nor correlates to petrographic or chemical subgroups that are identified to a particular production site or chronological span of time. The production of Albissola can, however, easily discriminate from the other manufacturing centers in France and Spain.

In conclusion, the main result of this study is that the taches noires wares retrieved in the region of Fort Liberte were produced in Albisola and can be dated before the 1820s, when the French Empire imposed extra duties on the importation of Albisola ceramics in its territories, with the consequent final collapse of the Albisola production and economy. These imports were found in the same archaeological contexts as the French colonial wares and English pearlwares. Therefore, the most probable interpretation of those finds is that they are attributed to the colonization period and transported into Haiti by transalpine traders.

The presence of English wares dating from the nineteenth century onwards (Monroe 2017:23) in northern Haiti found associated with French and Ligurian imports in the same context (terre cuite verte, faïence blanche, faïence brune, ceramics from Saintonge, Biot, and the Huveaune valley) clarify two important aspects of the Kingdom of Christophe. First, the new political organization in the North of Haiti promoted trade with the British Empire (Fick 2000:31), and the German states to purchase large quantities of European luxury goods (Pestel 2019:81). Second, the presence of colonial wares related to French domination together with new English wares in the same archaeological contexts, is more evidence of post-independence continuity in the use of places in the area of Fort Liberté. Christophe's Kingdom maintained the plantation system. Large lands were granted to a new high class and the tastes or perhaps, the only new elite products available, is demonstrated by the presence of English wares.

This research adds new information to this Haitian period of post-independence, clarifying the northern kingdom's relationship and international connections with the British Empire and the decline of imports from Italy through French traders. Furthermore, other avenues of research are proposed here. Future studies should focus on understanding the presence of taches noires ceramics and other imported objects, such as English wares, in other parts of the island. The southwestern republic, ruled by Pétion, had a different organization from the north. Pétion dismantled the plantation system and promoted more equal distribution of the land to soldiers and farmers. An investigation on the ceramic materials would allow the exploration of how a different social and economic organization might have impacted the importation and/or request of foreign objects by the population.

Another important aspect that requires further study is the production of utilitarian goods. Previous investigations in other areas of the Caribbean demonstrated that slaves commonly produced locally handmade, undecorated ceramics and that these products were extensively exchanged in local Black markets (e.g., Armstrong 2003; Armstrong and Fleischman 2003; Armstrong and Hauser 2009; Armstrong and Kelly 2000; Delle 1999; Haviser 1999; Hauser 2008, 2011; Wilkie and Farnsworth 1999, 2005). Here new questions arise: (1) how were the Haitian Black markets organized in comparison with other colonies, and (2) how did those productions and trades evolve after independence? 
To understand the life of the newly emancipated Haitians, we need to connect each aspect of colonial society with that of postcolonial life. Our knowledge of this period would benefit by a thorough understanding of slave manufacturing traditions (e.g., Smith 1995:335-374), which implied learning "how to do", making, using, and discarding objects of daily use, such as ceramics. Consequently, bridging the knowledge with a thorough understanding of manufacturing traditions of the independence period will allow the clarification of the transformation of habits of the newly emancipated population of Haiti.

This study demonstrates how the combination of microscopic and compositional analytical techniques (SEM-EDS and ICP-OES) performed on taches noires wares has allowed a discussion on several critical aspects of the manufacturing process of this globally exported earthenware and its relation to Haitian history. The first chemical data obtained with ICP-OES are provided for a number of taches noires wares produced in Albisola in addition to previous optical microscopy and SEM-EDS analyses. This new reference group will be of great importance for future provenance studies on the Ligurian ware, which is a key chronological marker for historical archaeology, not only of the Mediterranean, but also of the Americas. Historical archaeology has strong potential to clarify and add knowledge to the Haitian history. This paper shows the possibilities of this type of research, and we plead for more future investigations and collaboration between historians and archaeologists (and archeometrists as well) to promote multidisciplinary studies in order to unravel the complex transformations Haitian society experienced after the war of independence.

Acknowledgments The authors thank Rosemarijn Hofte, Ward Berenschot and Cameron Monreo for their important ideas in structuring the research, and Teodora Polyak for her help in some of the analysis of the glaze with the SEM-EDS. We gratefully acknowledge Silvana Gavagnin and the Soprintendenza Archeologia, Belle Arti e Paesaggio per la città metropolitana di Genova e le province di Imperia, La Spezia e Savona for providing the samples from Albisola, and Andy Ciofalo, Gene Shev and Gregory Tonks for their fundamental suggestions in editing the text. Special thanks go to people in Fort Liberté for their help during the survey and the director of the Bureau National d'Ethnologie in Haiti, Erol Josué, for providing administrative assistance during this fieldwork. We express gratitude to Barbara Checcucci, Patrone Gerolamo and Patrone Francesco for their contribution with pictures of the taches noires and finally, to Finn van der Leden for his input in the editing of the images.

Funding This research was partially funded by the ERC-Synergy NEXUS1492 project grant agreement number 319209.

\section{Compliance with Ethical Standards}

Conflict of Interest The authors declare that they have no conflict of interest.

Open Access This article is licensed under a Creative Commons Attribution 4.0 International License, which permits use, sharing, adaptation, distribution and reproduction in any medium or format, as long as you give appropriate credit to the original author(s) and the source, provide a link to the Creative Commons licence, and indicate if changes were made. The images or other third party material in this article are included in the article's Creative Commons licence, unless indicated otherwise in a credit line to the material. If material is not included in the article's Creative Commons licence and your intended use is not permitted by statutory regulation or exceeds the permitted use, you will need to obtain permission directly from the copyright holder. To view a copy of this licence, visit http://creativecommons.org/licenses/by/4.0/. 


\section{References}

Amouric, H., Vallauri, L., and Capelli, C. (2016). Terre cuite glaçurée ligure d'Albisola-Savona. In Métreau L. (ed.), Identifier la céramique au Québec. Cahiers d'archéologie du CELAT, 41, Québec, pp. 103-106.

Annetta, E. and Bulgarelli, F., (2001). Ceramica romana e postmedievale dalla villa Mansio di Albisola. Primo contributo per un'analisi quantitativa. Atti XXXIII Convegno Internazionale della Ceramica, Albisola, 2000, pp. 295-301.

Armstrong, D. V. (2003). Creole Transformation from Slavery to Freedom: Historical Archaeology of the East End Community, St. John, Virgin Islands. University Press of Florida, Gainesville.

Armstrong, D. V. and Hauser, M. W. (2009). A sea of diversity: historical archaeology in the Caribbean. International Handbook of Historical Archaeology 13: 583-612.

Armstrong, D. V. and Fleischman, M. (2003). House-Yard Burials of Enslaved Laborers in EighteenthCentury Jamaica. International Journal of Historical Archaeology 7: 33-65.

Armstrong, D. V. and Kelly, K. G. (2000). Settlement patterns and the origins of African Jamaican society: Seville plantation, St. Ann's Bay, Jamaica. Ethnohistory 47: 369-397.

Arum, J. J. and Garcia-Arevalo, M. (1986). Cimarron. University Press of Florida, Gainesville.

Barka, N. F. (1996). Citizens of St. Eustatius, 1781: a historical and archaeological study. In Paquette, R. L. and Engerman, S. L. (eds.), The Lesser Antilles in the Age of European Expansion, University Press of Florida, Gainesville, pp. 223-240.

Beltrán de Heredia Bercero, J., Capelli, C., Di Febo, R., Madrid i Fernández, M., Buxeda i Garrigós, J. (2015). Imitaciones de ceràmicas à taches noires en Barcelona en el s. xviii. datos arqueológicos y arqueométricos. In Actas do X congresso Internacional a Ceràmica Medieval no Mediterraneo, Silves, pp. 277-293.

Bulgarelli, F. and Geltrudini, F. (2013). Indagini archeologiche in Via San Pietro (Albisola Superiore). In Del Lucchese, A., Gambaro, L., and Gardini, A. (eds.), Archeologia in Liguria, N.S., Vol. III - 2008-2009. De Ferrari, Genova, pp. 141-143.

Cameirana, A. (1980). La ceramica albisolese a "taches noires". In Atti X Convegno Internazionale della Ceramica, 1977, pp. 277-293.

Capelli, C. and Cabella, R. (2013). Le radici di una produzione a diffusione internazionale. La storia della ceramica di Savona e Albisola dal punto di vista dell'archeometria. In Sborgi, F. and Bochicchio, L. (eds.), Ceramica contemporanea all'aperto. Studi sulla conservazione e il restauro. Atti della Giornata Internazionale di studi di Albissola Marina, 14 ottobre 2011. Aracne, Rome, pp. 45-62.

Capelli, C., Richez, F., Vallauri, L., Cabella, R., and Di Febo, R. (2013). L'épave du Grand Congloué 4: caractérisation archéologique et archéométrique d'un lot de céramiques à tâches noires de AlbisolaSavona. Navi, relitti e porti: il commercio marittimo della ceramica medievale e postmedievale. In Atti XLV Convegno Internazionale della Ceramica, Savona, 25-26 maggio 2012, Savona, Italy, pp. 7-16.

Capelli, C., Cabella, R. (2015). Technological transfer and trade routes of glazed wares in Medieval and postMedieval times in the western Mediterranean: "Global pottery" from Savona and Albisola (Liguria, Italy). In Buxeda, . G. J., Madrid, . F. M., and Iñañez, J. G. (eds), GlobalPottery - Internationa Congress on Historical Archaeology and Archaeometry for Societies in Contact. Archaeopress, Oxford, pp. 27-36.

Capelli, C., Di Febo, R., Amouric, H., Cabella, R., and Vallauri, L. (2017). Importazioni e imitazioni locali di ceramica a taches noires in Provenza nel XVIII-XIX secolo. Dati archeologici e archeometrici. In Atti XLIX Convegno Internazionale della Ceramica 2016, pp. 339-345.

Cary, H. (2019). Quelques perspectives des rapports "paradiplomatiques" entre la Prusse de Friedrich Wilhelm III. et le Royaume d'Henry Christophe (1811-1820). Revue de la Société haïtienne d'histoire, de géographie et de géologie, nr. 245-248, 2012, pp. 182-02.

Chabrol De Volvic, G. (1824). Statistiques des Provinces de Savone, dóneille, d'Acqui et de Partie de la Province de Mondoví, formant l'ancien Département de Montenotte. Paris.

Deagan, K. A. (1995). Puerto Real: The archaeology of a sixteenth-century Spanish town in Hispaniola. University Press of Florida, Gainesville.

Deagan, K. A. and Cruxent, J. M. (2002). Archaeology at La Isabella: America's first European Town. Yale University Press, New Haven, CT.

Delle, J. (1999). The landscapes of class negotiation on coffee plantations in the blue mountains of Jamaica: 1790-1850. Historical Archaeology 33(1): 136-158.

Delle, J. A., Hauser, M. W., and Armstron, D. V. (eds.) (2011). Out of many, one people: the historical archaeology of Colonial Jamaica. University of Alabama Press, Tuscaloosa. 
Di Febo, R., Casas, L., Capelli, C., Cabella, R., and Vallcorba, O. (2018). Catalan imitations of the Ligurian taches noires ware in Barcelona (18th-19th century):an example of technical knowledge transfer. Minerals 8: 183.

Dillon, E. M. and Drexler, M. (2016). The Haitian Revolution and the Early United States: Histories, Textualities, Geographies. University of Pennsylvania Press, Philadelphia.

Domínguez, L. (1989). Arqueología Colonial Cubana: Dos Estudios. Editorial de Ciencias Sociales, Havana.

Domínguez, L. (1991). Arqueología del Centro-Sur de Cuba. Editorial Academia, Havana.

Garraway, D. L. (2012). Empire of freedom, kingdom of civilization: Henry Christophe, the Baron de Vastey, and the Paradoxes of Universalism in Post Revolutionary Haiti. Small Axe 16: 1-21. https://doi. org/10.1215/07990537-1894069.

Dubois, L. (2005). Avengers of the New World. Harvard University Press, Cambridge, MA.

Dupuy, A. (2019). Rethinking the Haitian Revolution: Slavery, Independence, and the Struggle for Recognition. Rowman and Littlefield, Lanham, MD.

Ewen, C. R. (1991). From Spaniard to Creole: The Archaeology of Cultural Formation at Puerto Real, Haiti. University of Alabama Press, Tuscaloosa.

Fairbanks, C. and Marrinan, R. (1983). The Puerto Real Project, Haiti. Proceedings of the Ninth IACA, pp. $409-417$.

Fick, C. (2000). Emancipation in Haiti: From plantation labour to peasant proprietorship. Slavery and Abolition 21: 11-40.

Finlay, A., McComish, J., Ottley, C., Bates, C., and Selby, D. (2012). Trace element fingerprinting of ceramic building material from Carpow and York Roman fortresses manufactured by the VI Legion. Journal of Archaeological Science 39: 2385-2391.

Fricke, F., Laffoon, J., Victorina, A., and Haviser, J. (2020). Delayed physical development in a first generation enslaved African woman from Pietermaai, Curaçao. International Journal of Osteoarchaeology 30: 43-52. https://doi.org/10.1002/oa.2829

Garraway, D. L. (ed.) (2008). Tree of Liberty: Cultural Legacies of the Haitian Revolution in the Atlantic World. University of Virginia Press, Charlottesville.

Garraway, D. L. (2012). Empire of freedom, kingdom of civilization: Henry Christophe, the Baron de Vastey, and the Paradoxes of Universalism in Post Revolutionary Haiti. Small Axe 16: 1-21. https://doi. org/10.1215/07990537-1894069.

Geggus, D. (2014). The Haitian Revolution: A Documentary History. Hackett, Indianapolis.

Geggus, D. P. and Fiering, N. (eds.) (2009). The World of the Haitian Revolution. Indiana University Press, Bloomington.

Glascock, M. D., Neff, H., Stryker, K. S., and Johnson, T. N. (1994). Sourcing archaeological obsidian by an abbreviated NAA procedure. Journal of Radioanalytical Nuclear Chemistry 180: 29-35.

Ghachem, M. W. (2012). The Old Regime and the Haitian Revolution. Cambridge University Press, Cambridge.

Giammarino, S., Giglia, G., Capponi, G., Crispini, L., and Piazza, M. (2002). Carta Geologica della LiguriaScala 1:200000. Lab. Cartografia digitale e GIS del Dipartimento di Scienze della Terra dell'Università di Siena, Litografia Artistica Cartografica: Firenze, Italy.

Gilmore, R. G. (2006). All the documents are destroyed! documenting slavery for St. Eustatius, Netherlands Antilles. In Haviser, J. and MacDonald, K. C. (eds.), African Re-genesis: Confronting Social Issues in the African Diaspora, One World Archaeology Series. Routledge, London, pp. 70-90.

Gilmore, R. G. (2011). Caribbean capitalism and the archaeology of St. Eustatius. In Hofman, C. (ed.), Archaeology of the Netherlands Antilles and Aruba. Sidestone Press, Leiden.

Gómez, A. E. (2017). Le spectre de la Révolution noire: l'impact de la Révolution haïtienne dans le monde atlantique, 1790-1886. Presses Universitaires de Rennes, Rennes.

Gratuze, B. (1999). Obsidian characterization by laser ablation ICP-MS and its application to prehistoric trade in the Mediterranean and the Near East: sources and distribution of obsidian within the Aegean and Anatolia. Journal Archaeological Science 26: 869-881.

Grüner, E. (2019). The Haitian Revolution: Capitalism, Slavery and Counter-Modernity. John Wiley, Hoboken, NJ.

Hauser, M. (2008). An archaeology of black markets: local ceramics and economies in eighteenth-century Jamaica. African Diaspora Archaeology Newsletter 11:15.

Hauser, M. W. (2011). Routes and roots of empire: Pots, power, and slavery in the 18th-century British Caribbean. American Anthropologist 113(3): 431-44.

Haviser, J. B. (ed.) (1999). African Sites: Archaeology in the Caribbean. Markus Weiner, Princeton. 
Haviser, J. B. (2001). Historical archaeology in the Netherlands Antilles and Aruba. In Farnsworth, P. (ed.), Island Lives: Historical Archaeologies of the Caribbean. University of Alabama Press, Tuscaloosa, pp. 60-81.

Heath, B. (1988). Afro Caribbean Ware: A Study of Ethnicity on St. eustatius. University of Pennsylvania, Philadelphia.

Heath, J. (1999). Yabbas, monkeys, jugs, and jars: a historical context for African Caribbean potterys on St. Eustatius. In Haviser, J. B. (ed.), African Sites Archaeology in the Caribbean. Ian Randle, Kingston, Jamaica, pp. 196-220.

Heath, J. (2006). La Révolution Haïtienne au-delà de ses Frontières. Karthala Editions, Paris.

Hector, M. (2009). Une autre voie de construction de l'État-nation: l'expérience christophienne (1806-1820). In Hector, M. and Hurbon, L. (eds.), Genèses de de l'Etat haïtien (1804-1859). Editions de la Maisons de l'Homme, Paris.

Hector, C. (2019). Quelques perspectives des rapports "paradiplomatiques" entre la Prusse de Friedrich Wilhelm III. et le Royaume d'Henry Christophe (1811-1820). Revue de la Société Haïtienne d'Histoire, de Géographie et de Géologie 245-248: 182-202.

Hein, A., Tsolakidou, A., Iliopoulos, I., Mommsen, H., Buxeda i Garrigós, J., Montana, G., and Kilikoglou, V. (2002). Standardisation of elemental analytical techniques applied to provenance studies of archaeological ceramics: an inter-laboratory calibration study. Analyst 127: 542-553.

Horne, G. (2015). Confronting Black Jacobins: The US, the Haitian Revolution, and the Origins of the Dominican Republic. New York University Press, New York.

Jean, J. S. (2019). La Biographie d'un paysage: Etude sur les transformations de longue durée du paysage culturel de la région de Fort-Liberté, Haïti. Sidestone Press, Leiden.

Kelly, G. K. (2002). African diaspora archaeology in Guadeloupe, French West Indies. Antiquity 76: 333-334.

Kelly, G. K. (2004). Historical archaeology in the French Caribbean: an introduction to a special volume of the journal of Caribbean archaeology. Journal of Caribbean Archaeology 1: 1-10.

Kelly, G. K. (2013). La vie quotidienne des habitations sucrières aux Antilles: l'archéologie à la découverte d'une histoire cachée. In Situ. https://doi.org/10.4000/insitu.10160

Kelly, K., and Bérard, B. (eds) (2014). Bitation, archéologie des habitations/plantations des Petites Antilles. Sidestone Press, Leiden.

Kelly, G. K. (2009). Where is the Caribbean? French colonial archaeology in the English Lake. International Journal of Historical Archaeology 13: 80-93.

Lacerte, R. K. (1978). The evolution of land and labor in the Haitian Revolution, 1791-1820. The Americas 34: 449-459.

McIntosh, T. and Pierrot, G. (2017). Capturing the likeness of Henry I of Haiti (1805-1822). Atlantic Studies 14: $127-151$.

Moïse, C. (1988). Constitutions et Luttes de Pouvoir en Haïti, 1804-1987. Editions du CIDIHCA, Montréal.

Monroe, J. C. (2017). New light from Haiti's royal past: recent archaeological excavations in the Palace of Sans-Souci, Milot. Journal of Haitian Studies 23: 5.

Munro, M. and Walcott-Hackshaw, E. (eds) (2006). Reinterpreting the Haitian Revolution and its Cultural Aftershocks. University of West Indies Press, Kingston, Jamaica.

Nesbitt, F. N. T. (2008). Universal Emancipation: The Haitian Revolution and the Radical Enlightenment. University of Virginia Press, Charlottesville.

Pestel, F. (2019). Une restauration atlantique: légitimations politiques, cultures matérielles et mobilité entre les pays germaniques et Haïti, 1804-1825. Annales Historiques de la Révolution Française 397: 77-97.

Popkin, J. D. (2010). You are All Free: The Haitian Revolution and the Abolition of Slavery. Cambridge University Press, Cambridge.

Popkin, J. D. (2011). A Concise History of the Haitian Revolution, Vol. 3. John Wiley, Hoboken, NJ.

Quinn, P. S. (2013). Ceramic Petrography: The Interpretation of Archaeological Pottery and Related Artefacts in Thin Section. Archaeopress, Oxford.

Reed, S. J. B. (2005). Electron Microprobe Analysis and Scanning Electron Microscopy in Geology. Cambridge University Press, Cambridge.

Reitz, E. J. (1986). Vertebrate fauna from Locus 39, Puerto Real, Haiti. Journal of Field Archaeology 13: 317328.

Restagno, D. (1976). Primi risultati di un'indagine sulle antiche fornaci di Albisola. Le fornaci di Albisola Superiore e della frazione Capo tra XVII e XVIII secolo. In Atti IX Convegno Internazionale della Ceramica, pp. 351-384.

Rice, P. M. (1987). Pottery Analysis: A Sourcebook. University of Chicago Press, Illinois. 
Sharrat, N., Golitko, M., Williams, P. R., and Dussubieux, L. (2009). Ceramic production during the Middle Horizon: Wari and Tiwanaku clay procurement in theMoquegua Valley, Peru. Geoarchaeology 24: 792820 .

Smith, G. (1995). Indian and African at Puerto Real: The ceramic evidence. In Deagan, K. A. (ed.), Puerto Real: The Archaeology of a Sixteenth-century SpanishTown in Hispaniola. University Press of Florida, Gainesville, pp. 335-374.

Woodward, R. P. (2011). Feudalism or agrarian capitalism? the archaeology of the early sixteenth century Spanish sugar industry. In Delle, J., Hauser, M., and Armstrong, D. V. (eds.), Out of Many, One People: Historical Archaeology in Jamaica. University of Alabama Press, Tuscaloosa, pp. 23-40.

Whitbread, I. K. (1986). The characterization of argillaceous inclusions in ceramic thin sections. Archaeometry 28:79-88.

Williams, M. W. (1986). Sub-surface patterning at Puerto Real: a 16th century town on Haiti's north coast. Journal of Field Archaeology 13: 283-296.

Wilkie, L. A. and Farnsworth, P. (1999). Trade and the construction of Bahamian identity: a multiscalar exploration. International Journal of Historical Archaeology 3: 283-320.

Wilkie, L. A. and Farnsworth, P. (2005). Sampling Many Pots: An Archaeology of Memory and Tradition at a Bahamian Plantation. University Press of Florida, Gainesville.

Publisher's Note Springer Nature remains neutral with regard to jurisdictional claims in published maps and institutional affiliations.

\title{
Affiliations
}

\section{Simone Casale ${ }^{1,2} \cdot$ Joseph S. Jean ${ }^{1,2} \cdot$ Claudio Capelli $^{3} \cdot$ Dennis Braekmans $^{1,4,5,6}$. Patrick Degryse $^{1,6} \cdot$ Corinne Hofman ${ }^{1,2}$}

\author{
Joseph S. Jean \\ jean@kitlv.nl \\ Claudio Capelli \\ claudio.capelli@edu.unige.it \\ Dennis Braekmans \\ dennis.braekmans@cranfield.ac.uk \\ Patrick Degryse \\ patrick.degryse@kuleuven.be \\ Corinne Hofman \\ c.1.hofman@arch.leidenuniv.nl
}

1 Faculty of Archaeology, Leiden University, Einsteinweg 2, 2333 CCLeiden, The Netherlands

2 Royal Netherlands Institute of Southeast Asian and Caribbean Studies, Reuvensplaats 2, Postbus 9515, 2300 RALeiden, The Netherlands

3 Dipartimento di Scienze della Terra, dell'Ambiente e della Vita (DISTAV), Università degli Studi di Genova, Corso Europa 26, 16132 Genova, Italy

4 Cranfield Forensic Institute, Cranfield University, Defence Academy of the United Kingdom, Shrivenham SN6 8LA, UK

5 Materials in Art and Archaeology, Materials Science and Engineering, TU Delft, Mekelweg 2, 2628CD Delft, The Netherlands

6 Division of Geology, Department of Earth and Environmental Sciences, Celestijnenlaan 200E, 3001 Leuven, Belgium 